\title{
Elder care allowances in action: missed opportunities for gender transformation
}

\author{
Clémence Ledoux. Annie Dussuet
}

\section{Introduction}

Elder care is a highly feminized domain. In France, like in other European countries, a majority of elder care receivers, informal helpers or paid care workers are women (Lewis 1998; Hobson, Lewis, and Siim 2002; Daly and Rake 2003; Dus- suet 2005; Morel 2007; Le Bihan and Martin 2010; Bonnet et al. 2011; Ranci and Pavolini 2012; Avril 2014; Avril and Cartier 2014). This reflects three main social dynamics. Firstly, women have a higher life expectancy than men and therefore a majority of older people are women - over $69 \%$ of those aged over 85 in France in 20191, a large proportion of which are widows. At an equivalent age, women are more dependent than men (Brunel and Carrère 2017) and receive more public sup- port. Secondly, when older people are supported by their children, it is most often daughters who take on this role (Weber, Gojard and Gramain, 2003; Le Bihan and Martin 2010; Bonnet et al. 2011). Older people living at home are often cared for informally and for free by women (relatives, spouses, children or neighbours) (Pennec, 1999; Renaut, 2000; Bonnet et al. 2011; Campéon, Le Bihan, and Martin 2012). In heterosexual couples, men are in many cases older than their spouse and female spouses are the default primary caregivers, given that they live with the care recipient. Thirdly, 95\% of paid caregivers, both declared and undeclared, are female. Undeclared care workers are excluded from social security and suffer in many cases from multiple dominations. Declared workers can be directly employed by families, by non-profit organizations or by local authorities, but even so, in most cases, expe- rience great professional precariousness (Dussuet 2005; Morel 2007; Barrois and Devetter 2012; Avril and Cartier 2014).

Thus, although elder care is not explicitly a feminist issue, it is highly suitable for studying whether and how public policy can promote and achieve gender equality through "gender transformation (Engeli and Mazur 2018)". We focus here on the Elder Care Allowance (APA) since 2001 as a crucial elder care policy; its adoption at the national level in a 2001 Act and then the policy's implementation, evaluation and impact in practice in one department are based on in-depth fieldwork. Previous research has already shown the variations in departmental decisions and ways of organizing implementation of public policies from one department to another (Frin- ault 2009,

\footnotetext{
${ }^{1}$ https://www.ined.fr/fr/tout-savoir-population/chiffres/france/structurepopulation/population-sexe-ages/
} 
Fouquet et al. 2009; Devetter et al. 2017; Leroux 2018); but only a small number of studies (Mulet 2014; Giraud et al. 2014; Gramain et al. 2015; Fondation Médéric Alzheimer 2019) have really looked at the activities of the actors putting in place schemes on a daily basis in order to understand what room for manoeuvre they may have, as street-level bureaucrats (Lipsky 1980).

Appreciating the extent of this room for manoeuvre requires in-depth analysis, we therefore decided not to study a variety of departmental contexts but to focus instead on one department, which was considered to be a model in the $1980 \mathrm{~s}$ and $1990 \mathrm{~s}$ by the central state (Nogues et al. 1984) and where the medical professions have played a particularly strong role in implementation of the APA. In order to better understand the possibilities in terms of room for manoeuver inherent to APA implementation, we conducted in-depth research in the department from 2013 to 2019, including interviews with street-level bureaucrats, archival research, participant observation and focus groups. $^{2}$

As our analysis shows, despite elder care being highly feminized, this policy instrument was gender blind when it was put on the agenda and adopted. The finegrained case study of the departments demonstrates how in practice, the room for manoeuvre existing at departmental level has not been used to reduce gender inequality, while a recent movement of gendering policy evaluation at the national levelhas not yet produced significant effects. Nevertheless, the APA is a capacity instru- ment that has changed elder care, for older people as well as for their relatives and care workers.

In the rest of the article, we first cover agenda setting and adoption on the APA, before examining in greater detail the gendered dimensions of this policy instrument. We then look at the practices of APA implementation in a French department in the next section and in the following section identify some of its main outcomes. To better understand the politics of elder care more broadly speaking and more specifically in the APA, it is important to first place French policy in a broader comparative European context.

\footnotetext{
2 More specifically, we conducted 36 in-depth interviews with members of the department among whom 25 were directly in charge of team management, dependency evaluation or negotiation of the per-sonalized help plans with the public. The 25 civil servants we interviewed represented $54 \%$ of the 46 civil servants in charge of these tasks. The 11 other interviewees were involved in the administrative or political production of the APA but also had other responsibilities. We also collected not only numerous administrative documents available on the websites of the department and at its administrative offices but also documents distributed by frontline workers' managers. We also observed 7 of the weekly meetings during which members of the 6 territorial teams working in the department present the help plan proposals to be validated by the territorial unit manager. This analysis was completed with the results of 3 focus groups carried out in 2013 by the French team working on the FLOWS European Program (2011-2014) "Impact of local welfare systems on female labor force participation and social cohesion". These focus groups brought together working women who had a dependent older relative with care needs (Bigoteau and alii, 2015). All these elements helped us to better understand the possibilities in terms of room for manoeuver inherent to APA implementation.
} 


\section{Situating France in the European context}

The different welfare state regimes in European countries structure the care sector and produce national disparities that have been analysed through various typologies (Lewis 1992; Anttonen and Sipilä 1996; Jenson 1997; Leitner 2003; Morel 2007; Ranci and Pavolini 2012; Van Hooren, Apitzsch and Ledoux 2019). Esping-Andersen's wellknown distinction between social-democratic, liberal and corporatist regimes (EspingAndersen 1990), criticized for failing to highlight the effects of inequalities between men and women as regards care and domestic work, has been completed by other authors who have taken gender issues into account (Lewis 1992; Anttonen and Sipilä 1996; Jenson 1997; Leitner 2003; Cic- cia and Sainsbury 2018). For example, Anttonen and Sipilä (Anttonen and Sipilä 1996) contrast northern European countries, where the welfare state provides care services, with southern countries, where families are encouraged to pay for care services on the informal or grey market or to provide them themselves (ibid: 96).

Despite these differences, major changes have occurred in the care policies of European countries since $1990 \mathrm{~s}$, with care being one of the rare policy domainsto have experienced welfare state expansion in the $2000 \mathrm{~s}$. These policy reforms include a growing budget dedicated to elder care, the privatization of public care services and the introduction of cash-for-care schemes, in which the care recipient receives public subsidies to purchase care services on the market (Morel 2007; Ranci and Pavolini 2012). These changes have been analysed as recasting the relationship between families, states and the market and as participating in the trans- formation of gender relations and norms. After the mid-1990 s, at both European and national level, care policies began to be used to raise female employment levels (Morel 2007) in a context in which, unlike in the past, women are expected to work rather than stay at home. How then have French elder care policies been affected by these tendencies and how have they changed policy implementation?

Until the end of the 1990s, though "modified", French social policies in general were still largely based on a male bread-winner model (Lewis 1992). France alternated between "optional familialism" in childcare and "explicit familialism" in eldercare (Leitner 2003; Morel 2007). In the optional familialism model, "the caring family is strengthened but is also given the option of being (partly) relieved of its caring responsibilities", while explicit familialism "explicitly enforces the caring function of the family because of the lack of public and market-driven care provision coupledwith strong familialization" (Leitner 2003 : 358-9). For childcare, policies at this time were contradictory (Commaille 2001; Sineau and Jenson 2003), as the caring family was strengthened, but also given the option to be (partly) unburdened of caring responsibilities. In elder care, the main social policy used by older people was not designed for them and was far from sufficient for their needs (Morel 2007; Le Bihan and Martin 2010). It is in this context that a law establishing a new eldercare 
allowance, the Allocation Personnalisée pour l'Autonomie (APA), was passed in France in 2001 and implemented. The APA policy follows the general European trend towards the development of cash-for-care schemes supporting home care, justi-fied by the idea that home care is less costly than residential care and that older peo-ple wish to stay in their own home as long as possible (Ungerson and Yeandle 2007; Da Roit and Le Bihan 2010; Ranci and Pavolini 2012). For example, long-term care insurance had been introduced in Germany a few years before, in 1994, proposing either services or cash (Ledoux 2018). Nevertheless, one of the specificities of the French cash-for-care allowance in comparison with other countries was the greater control over the scheme granted. While in the German cash-for-care scheme families can pay whoever they want for care, without needing to establish a written con- tract with the caregiver, in France, the scheme is based on a personalized help plan which requires users to pay for formal services or employ a declared worker withan employment contract. Care workers' professional practices and qualifications are not, however, subject to French governmental authorities.

\section{The gender-blind frame in agenda setting and APA adoption}

Gender did not play a role in the processes of problem definition and agenda setting for the APA. The question of elder care was mainly conceptualized and puton the agenda as related to the problem of poverty among older people and as a financial problem for local authorities. Until the 1970s, long-term care was mostly seen as a problem for older people who were unable to buy services to help them to stay in their homes. The decision to encourage people to stay at home instead of entering institutional care was taken very early (Commission d'étude des problèmes de la vieillesse, 1962 (2014)), but no differences were identified between the situation of men and women and the situation of those (women) who provided care services was not discussed as a problem. From the late 1970s, Members of Parliament, of the Commissariat Général du Plan and of the Social and Economic Council anticipated demographic imbalances and growing problems relating to poverty for older people. Various reports were written, a State Secretary for Older People was established, a National Committee representing pensioners and older people was created in 1982 (Comité National des Retraités et des Personnes Agées-CNRPA) and a Convention of Older People was held in 1983, but the specific problems of women (lower retirement pensions, greater isolation...) were not mentioned.

From the beginning of the 1980s, associations providing home-based care to older people began to criticize existing allowances and advocated for the acknowledgement of a supported service, financed through the creation of a "fifth risk" ("disability, invalidity and dependency"), separated from the four other risks which already structured the branches of the French social security system. However, the associations representing disabled people and their families refused the stigma of old 
age and the creation of a common risk covering both disabilityand old-age dependency (Ledoux 2018). Again, the fact that women were more often concerned by dependency was not discussed and the situation of care workers (mostly women) was not directly addressed in the debate. Indeed, careworkers' voices were not represented: only the non-profit federations of associations spoke in the name of older people, care providers and their workers.

Local and national women's groups also did not get involved in these debates. In the journal of the Mouvement de Libération des Femmes, "Le Torchon brûle", many articles advocated for more childcare facilities and a more equal sharing of domestic work, but no reference was made to ageing and care of older people (Ledoux 2011). This might be explained by a reluctance to confront the question of death but also by the difficulty of "de-biologizing" the ageing process (Lagrave 2009). Since ageing was mainly conceived as a biological process that diminished capacities, it was difficult at that time to imagine ageing processes as structured by social constructions.

The political context should also be considered. At the beginning of the 1980s, departments had obtained the responsibility for the management and funding of social assistance, previously administered by the central state. The departments had no desire to abandon this new competence by supporting a fifth risk managed by the social insurance system. Instead, they mobilized to successfully block the insurance solution several times over the 1990s, while at the same time being in favour of a reform that would enable them to better control their funding flows (Frinault 2009).

Finally a solution was found in which the departments were able to conserve their authority in this area. A new specific long-term care allowance (PSD, "Prestation spécifique dépendance”) was first tested and then introduced in 1997 under a right- wing government. It allowed care payments to be made to recipients while they werestill alive and then recovered from their estate after their death. This clause was immediately criticized and considered to be a major obstacle for accessibility to the funded services.

Indeed, the social movement against the PSD rapidly put the problem of care needs back on the political agenda. After the left won the 1997 election, socialist Prime Minister Lionel Jospin considered the sector of elder care to be one of the most important areas for reform. Under his government, the National Assembly decided to abolish the inheritance clause of the PSD. In the Assembly, while the Commissions in charge of Social Affairs and Finances seized on the chance to be involved in the reform of the PSD and wrote reports on the governmental proposal, the delegation for equal rights between women and men (Délégation aux droits des femmes et à l'égalité des chances entre les hommes et les femmes) was not asked and did not decide to work on it. The same happened in the Senate. These elements demonstrate that the PSD reform was not perceived as a reform concerning gen-der equality. At that time, the equal rights delegations had just been formed and were occupied by other issues (such as the 35-h working week, parity reform, a bill on contraception and abortion, another on professional equality and the reform of divorce laws). The PSD was finally replaced by 
the personal autonomy allowance (APA-Allocation Personnalisée d'autonomie) in 2001. Within this new scheme, public authorities could no longer claim part of the older person's estate after their death and the allowance granted was henceforth dependent on the beneficiary's income and level of dependency.

This scheme has not profoundly changed since 2001-2002. In 2004, following the 2003 heat wave which caused the deaths of thousands of older people, a new employerbased social contribution was created to partly finance the APA and a new institution, the Caisse Nationale de Solidarité pour l'Autonomie (CNSA) was charged with pilot-ing APA implementation. However, the new social contributions were not enough tofully fund the allowance, and the departments continued to finance the APA from theirown resources. In 2011, under the Sarkozy Presidency, a great public debate on eldercare was held in which many stakeholders were invited to participate. For the first time, the delegation for equal rights between men and women at the National Assembly became involved. In its report (Dubois 2011), it considered all the inequalities women were confronted with in elder care and underlined that, compared to men, women weremore directly concerned by ageing and dependency, had less resources to pay for services, were more solicited to care for their spouse or parents and constituted $99 \%$ of the paid care workforce but occupied bad jobs. In its recommendations, the delegationinsisted on the need to professionalize the elder care sector. No decision was taken following this report, but for the first time, care for older people was really problematizedin terms of gender inequality within the National Assembly.

The most important APA reform was discussed in 2014 and passed in December 2015 (Loi d'Adaptation de la Société au Vieillissement-ASV Law), integrating one ofthe recommendations of the delegation for equal rights between men and women, theright to respite. It changed the allowance incrementally, by basing the percentage ofcost-sharing on the degree of dependence and by acknowledging the role played by informal helpers. The latter were given the possibility of taking care recipients to a residential home or receiving a greater concentration of care services during a short timeperiod, in order to have a vacation or "respite" from care. Here again, the delegation wrote a report on the bill before it passed, and its most important requests were that gender categories be introduced into statistics pertaining to elder care and that the high council for equality between men and women (Haut conseil à l'égalité entreles femmes et les hommes) be represented at the high council on age (Haut Conseil de l'Age) (Moignard 2014). Although the decree aimed at gendering the statistics wasonly recently adopted (December 2018, during our fieldwork), this legislative debate initself made the national elites more attentive to gender questions.

Despite the fact that the reform from PSD to APA occupied a large space on the political agenda between 1998 and 2002, there was nonetheless no explicit consideration given in the political arena to the gender of those who were cared for and those who were caring before 2011. As in many other policy domains, gender did not participate in framing the debate during the adoption phase, as the problem was seen aspurely 
related to dependent older people. This corresponds to the French tradition ofrepublican universalism, which refers to "the idea that granting rights and equality toindividuals as abstract figures, not as concrete group members, is a potential tool foremancipation" (Lépinard and Mazur 2009: 248). Formal neutrality and abstract universalism made it impossible to "raise issues of gender differences which are centralto any treatment of sexbased inequalities" (ibid), masking the differential treatment ofwomen. Feminist groups and women's policy agencies did not intervene in the debatesbefore 2011, even though this policy domain was characterized by huge gender inequalities. Taking feminist considerations into account earlier could have led, alreadyin 2000-2001, to demands for higher state funding and to more attention being paid towomen's work and to the idea of care activities as work. According to Nancy Fraser's normative framework, these considerations could have thus prevented the exploitation, time-poverty and marginalization of women, giving them the possibility to fullyparticipate in society and creating the incentives for men to also be caregivers (Fraser 1994). This could have contributed to a reduction in gender inequalities by reducing theburden on informal unpaid caregivers, mostly women, and by highlighting the workdone by paid home-based care workers, who are also almost exclusively women. How-ever, the invisibility of gender in the initial debates led to the creation of a gender-blindpolicy instrument.

\section{The APA: a gender-blind policy instrument}

Different policy implementation instruments do not convey the same principles, ideas, resources and constraints (Lascoumes and Le Galès 2005; Howlett 2010). What are those of the APA? APA-funded services can be delivered in an institution or in the recipient's home. In institutional care, the APA only finances the expenses related to care needs (tarif dépendance) and does not cover accommodation (paid for by users or by social aid) or medical expenses (paid for by the national health insurance system). In the recipient's home, the APA covers some costs of a "help plan" proposed by the public authorities but users must often also pay fees depending on their personal situation. However, public authorities are not obliged to provide the services themselves and a welfare market for care services has grown up around this allowance. The APA, as a policy instrument, is characterized by its gender blindness. The law targets "older persons unable to assume the consequences of their loss of autonomy", later labelled in the law as "the beneficiaries". Those concerned by this policy are therefore considered as abstract individuals. In its original form, before 2015, unpaid informal helpers (family, neighbours) were invisible in the law, with little mention made of the paid workforce delivering the services; when they were mentioned, it was always in an abstract form under the denomination of "the services".

In this article, we focus on home-based APA implementation, because it is in this sector, more than in residential care, that people are treated individually, and receive individually designed assistance. The APA is an instrument that distributes resources 
for funding help plans in the recipient's home and can therefore be considered to be a capacity instrument (Engeli and Mazur 2018). For home- based care, the APA provides a payment which is conditional on the establishment by the departments of a "help plan", realized by other agencies. The APA law and decrees define the eligibility conditions for receiving the allowance, the user fees and the services available. We will now scrutinize the gender implications of these characteristics, taking into account eligibility, calculation of user fees, the services provided in the help plan, the sources of financing for the APA and its governance.

\section{Eligibility criteria}

The APA law and decrees define the model to be used to establish individuals' degree of dependency and therefore the financial help they can receive. Dependency levels are classified according to Iso-resource Groups (IRG or in French "Groupes Iso Resources"-GIR), based on the national Gerontology Autonomy grid (Autonomie Gerontologie-Groupes Iso-Ressources), referenced hereafter as the "AGGIR". Of the 6 IRG (GIR) defined on the AGGIR, four are entitled to financial help from the APA. The highest APA is accorded to those included inthe IRG 1-which corresponds to the most dependent people "confined to bedor chair, whose mental functions are severely impaired or who require an indispensable and continuous presence" - and the lowest to those in IRG 4-which groups less-dependent older people.

According to many studies, the AGGIR, invented by geriatricians, imposes a medical definition of dependency (Ennuyer 2004). As in other countries, the conceptof Activity of Daily Living (ADL), coined by Sydney Katz and his team in 1963 in the Journal of the American Medical Association, provides the basis for this model (Belorgey 2017 : 167). Therefore, the grid defines people as dependent according totheir incapacity to do certain types of activities and considers dependency as a con- sequence of a physical or mental illness. The grid does not require information aboutpeople's social needs or take into account their socially acquired capacity to take care of themselves but merely measures the abilities of neutral abstract individuals. This means that women who have been more used to caring for themselves and older people surrounded by informal unpaid female caregivers are not considered less needy than people without informal (female) caregivers. In this case, republicanuniversalism seems to constitute a protection against delivering less to women or to people already assisted by informal caregivers, who are often women. Nevertheless, this protective dimension is counterbalanced by others.

\section{User fees}

The APA law and decrees also stipulate that the allowance be subject to costsharing, which means that a part of the help plan is paid for by the beneficiary, and this 
part increases/decreases according to his/her income. The higher a person's income,the higher his/her fees. Like many other allowances in France, corresponding to a familialistic logic, income is calculated on a household basis. This dimension was not publicly discussed during the debates in the assembly: Income tax papers on a household basis can be chosen as the proof of income status by street-level bureaucrats. In practice, it means that people living together with different individual incomes reach the higher percentage rates of user fees more quickly and will there- fore receive fewer benefits than if the poorest member of the household lived alone.It also means that in general, the public support for home-based care is proportion- ally greater for women living alone at home than for women living with a partner. However, although fees are calculated on a household basis, the help plans target individuals.

\section{The services provided in the help plan}

The APA is an instrument which enables older people to access services required due to their condition, excluding medical services which are provided throughhealth insurance. The help plans are individual: they are designed to help only one person in the household and if two individuals are dependent in the same household, then two plans are required. Children can be paid for care services by their parents with the APA only if they are their employees or employees of a provider organization and if they have signed an employment contract, but the APA cannot finance a spouse's caregiving. Moreover, help plan "evaluators" consider caregiving between spouses to be natural, a reflection of a loving relationship. Following this logic, theyalso seek less to replace this kind of "natural" caregiving with professional services, when people do not complain about it. This disproportionately affects women, as they are overrepresented among spousal caregivers. The central state thus contributes to shifting care in France from a model of unpaid work to paid and formal workbut this tendency does not affect all care work and does not change the way men andwomen share care activities, the majority of which continue to be shouldered by women.

\section{The funding and governance of the APA}

The central French state contributes to the financing of the APA by paying the departments through the social contribution collected by the CNSA. But as this funding is not sufficient, it is rationed out. The departments and their agents are the main actors in charge of APA implementation: they are responsible for diffusing information about the APA to potential beneficiaries, evaluating individual levels of dependency, calculating user fees, defining "help plans" and paying the allowance. Nevertheless, they do not provide the services themselves and rely on a welfare mar-ket. Provider organizations are approved by the departments and, depending on deci-sions taken at departmental level, either have their tariff imposed by the departments or fix it 
themselves.

\section{Room for manoeuvre at the departmental level: Implementation in Action}

We decided to concentrate our analysis on a department considered to be a modelin the 1980s and 1990s by the central state (Nogues, Bouget, Brovelli and Tymen 1984) and where the gender-neutral language based on republican universalism around the APA has been very strong, largely due to the high levels of involvement of the medical professions (Frinault 2009). It represents therefore an "extreme case" of universalism in practice. This department is characterized by its demographic dynamism and its economic attractivity. Here, people over 60 are less represented than in France generally $(22.7 \%$ against $24.5 \%$ ). This department is also characterized by a greater density of institutional elder care.

The main city of the department has had a long history of active feminist groups since the 1960s (Gallot and Meuret-Campfort 2015). Some of them federalized and institutionalized in a common structure (called here Espace B.) supported by the municipality and the state service in charge of women's rights (Service des droits des femmes). It is interesting to note that there was no evidence that these groups mobilized around APA implementation before the end of 2000s. At the end of the 2000s, they began to be more aware of elder care and to organize information sharing events. In 2010, Espace B. organized a conference on familial solidarity, and theNational Centre for Information on women's and family rights (CNIDFF) and its regional units launched a consultation on the status of informal helpers in 2017.

\section{Orienting APA applicants}

In the department studied, several devices are used to channel and routinize the applications for the APA. The services are devolved into six local units and in each unit three groups are responsible for different tasks relating to APA implementation:an administrative group for the reception of the administrative documents, the calculation of the fees and payment, a group of nurses and one or more doctors for the evaluation of the dependency level, and a team of administrative and social workers(the "evaluators") who design the help plans after visiting applicants' homes. The directors of the department defined a standard procedure for APA applicants, who have to fill in a "family" questionnaire, a statement of the capacities of the applicant (what he/she can do), household resources and to enclose, if possible, a medical questionnaire filled out by the family doctor. The medical questionnaire is not compulsory but highly recommended. In cases where needs have already been accurately assessed by a professional (in the hospital or by a social worker), an accelerated procedure can be used instead. After receiving the APA, it is always possibleto reevaluate needs and it 
is compulsory to do so after 5 years, as over time, people can change from one level of dependency (IRG) to another.

The IRG - and therefore the maximum level of APA funding available and the user fees calculated by the medical team - is evaluated first and help plans are defined subsequently. The dependency evaluation is carried out swiftly following the application, since a French law stipulates that in the absence of an answer from the administration within two months, applicants for social services should considertheir request granted ("silence vaut acceptation"). In order to not be obliged to pay for services for people who are not entitled to them, the medical team inform families of the applicant's IRG within this time frame. After that, the definition of a helpplan by the evaluators can take longer: up to six months in some cases.

While help plans are individualized based on applicants' physical situation, the social situations of applicants evaluated as having the same IRG can be different: some seniors live alone while others live with their spouse or other family members; some live isolated in the countryside without any services around while others live in a metropolitan area; some receive care from their relatives, others do not. These differences are identified by the evaluators:

I can propose a derogation for someone living alone, completely isolated. Per-haps there will be only housework and shopping done, but if it takes a long time to go shopping, the situation is different from someone living near the shop. ${ }^{3}$ This diversity leads to discussions, but during our research, the discourses we heard remained gender blind: the beneficiaries are described as "people", "the older per- son", "families" and we can imagine that the bureaucratic routines defined by the department favour this attitude.

\section{The definition of dependency in practice}

It should first be noted that in the department studied, the reduction in dependency to physical incapacities is exaggerated throughout the implementation process. Older people (or their families) and their doctor are each asked to fill out a questionnaire, but the ranking in different IRGs (see above), on which depend both eligibility for the allowance and its amount, is performed by doctors assisted by nurses. In the questionnaire completed by the family doctor, the medical history of the applicant and his/her capacities (vision, hearing, diet, behaviour and memory troubles) are described. It was the department, rather than the central state, that introduced the questionnaire filled in by family doctors; contrary to what is prescribed at national level for the APA, the departmental services do not go into the applicant's home to evaluate the level of dependency if the family doctor completes this questionnaire.

Although the needs of family careers and older people are also described through

\footnotetext{
${ }^{3}$ Interview with an evaluator, February 2018.
} 
the family questionnaire, the medical questionnaire completed by family doctors seems to be decisive. It should be underlined that family doctors have no relation with the departments as they interact with the health insurance system, which is a different institutional network. This means that most doctors do not benefit from anytraining related to these questions, and they may not be aware of the invisible needs and work done by informal care providers. The weight of the medical professions, which is greater in the department examined here than in other departments as several studies have showed (Frinault 2009; Daune-Richard et al. 2012; Gramain et al. 2015), focuses the evaluation of dependency on individual capacities and tends to render invisible the differences between men and women in everyday life that resultsfrom their differentiated socialization and position.

\section{The negotiation of the help plans in practice}

According to our interviews, in practice, families have often already begun to pay for services before the APA plan proposal, whether by employing an individual caregiver directly or through a provider organization. The plan then just helps to fund services which families have already engaged. For example, some evaluators often begin the interview in the applicant's home by asking about the services already funded by the family:

I often ask: "Are there things in place? Describe them to me", and "Is whatis in place satisfactory? What would improve the situation?". And if there is nothing in place, we can discuss it: "What would make you more comfortable in everyday life?"4

When no service has been used prior to the application for the APA, the social workers present the available services offered, specifying the amount that would be paid by the department and the share that users themselves would have to pay. This way of proceeding means that existing arrangements are often continued, with the dif- ference that the services are funded by the department instead of being paid for by the families themselves. Indeed, the intervention of the department does not aimat immediately replacing unpaid work or changing social norms. For example, one evaluator explains:

"the aim is not to force people. I am not in possession of all the facts. What I consider to be good for my mother is not necessarily adapted to somebody elsewho has other desires. I think that people's choices, their children's choices have to be respected." 5

Nevertheless, when autonomy declines, the department begins to finance new

\footnotetext{
${ }^{4}$ Interview with an evaluator, February 2018.

${ }^{5}$ Interview with an evaluator, April 2019.
} 
services. Our fieldwork was launched after the adoption of the ASV law acknowledging the role played by informal helpers and their right to respite. These objectives could be found in the interviews: the evaluators often explained that they also paid attention to informal helpers' level of fatigue, in order to prevent them becoming tooexhausted to continue their caregiving.

The social work team does not receive specific official instructions from the department to reduce the allocated amounts for financial reasons-and the Vice President confirmed that the APA "was a right". ${ }^{6}$ Nevertheless, the department studied tries to define standardized norms for home-based care services proposedto applicants: for example, it stipulates that a maximum of $13 \mathrm{~h}$ a month can be offered to older people with a dependency level of IRG 4 when only housework services were needed and $20 \mathrm{~h}$ when personal help (eating or taking a shower) was alsoneeded.

Before visiting the family, the evaluators often also call the children, to be sure they will be there. Sometimes, a representative of the providing organization is also present during the evaluator's visit.

Some evaluators explain that they try to find a "balance between the [people's] need, what we can finance and the money they can put in [to pay for the services themselves]". ${ }^{7}$ For them, real need does not always correspond to the need expressedby the families.

There are people to whom we have to explain that we do have rules [and can't finance everything they want] and on the contrary people who have many needs and who do not want much, so it's a negotiation in the end. ${ }^{8}$

Here, we also see how social norms intervene in the definition of appropriate serviceneeds. As in other departments, services associated with a middle-class living style (certain types of housework) are not considered appropriate for funding (Gramain et al. 2015). The APA is considered as designed to compensate for a loss of autonomy, not continue a standard of living. For example, one of the evaluators noticed:

When I go to a very big house, people explain that there is more housework needed, but I tell them: "the department is not here for that. ${ }^{9}$

The main aim of the evaluator's home visit is to encourage families to accept a helpplan and its conditions (user fees and amount of hours). At the end of the visit, the majority of the evaluators obtain applicants' consent. When we did our fieldwork, a new practice had just been introduced which involved all the help plans being dis- cussed in "medicosocial meetings", 7 of which we observed. These meetings were introduced to

\footnotetext{
${ }^{6}$ Interview with the Vice President in charge of older people at the Department, February 2018.

7 Interview with an evaluator, June 2018.

8 Ibid.

9 Interview with an evaluator, April 2019.
} 
harmonize practices between unit teams, but also allow team leadersto monitor and discuss the decisions taken by the evaluators. For the evaluators, these meetings are a resource enabling them to avoid blame by explaining to the families that they do not make their decisions alone. Nevertheless, these meetings also contribute to practices of routinization.

\section{The externalization of the services to providers}

Since the introduction of the APA, care funded by the allowance in the home canbe provided through direct employment of care workers by families or through a forprofit or non-profit providing organization. Previously absent from the sector of homebased elder care, the number of for-profit organizations has proliferated in thelast ten years, mainly in cities. In 2005, the so-called Plan Borloo encouraged directemployment and employment by firms by providing tax breaks for domestic work and decreasing social contributions (Devetter et al. 2009).

In the six territorial units of the department, the forms of the welfare market are different from one territorial unit to another: provider organizations are not evenly spread and for-profit providers are nearly absent in rural areas. In these areas, the offer of services is scarce, some evaluators explaining that even the non-profit organ-izations do not have the workforce necessary to carry out home visits everywhere. The provider organizations also refuse to work in remote areas for short periods. In these areas, the agents of the department explained to us they work "in partnership" with associations and take into account their material constraints ${ }^{10}$, because they know them very well, directing applicants towards them and discussing services andevaluation of individual situations with them.

To conclude, the directors of the departments have room to manoeuvre in the way they choose to organize bureaucratic work and to price the services, whereas streetlevel bureaucrats also have room to manoeuvre in their individual decisions, and the market itself influence the allocation of services. In the department studied, we observed a professional divide between the tasks carried out by doctors and nurses and those realized by evaluators, whose biases in their gender blindness were more pronounced than their medical colleagues. However, the gender blindness of the department studied can also be seen in the processes of assessment of the impactof the policy, which contrast with gendered evaluation techniques existing at the national or at the city level. 


\section{Gender-blind policy evaluation}

Policy evaluation of the APA is planned by the central state, which provides information on the instrument's implementation on its website. Although major policy evaluations have concentrated mostly on poverty rates among older people, gen- derbased assessments have also been carried out, showing how many women/men receive the APA, how many men/women live alone at home or how many live belowthe poverty threshold. National statistics provided by the central state, without being directly related to the APA, inform about the gender rates among unpaid informal carers and paid care workers. Very recently, the populations concerned by non- take-up have been evaluated (Ramos-Gorand 2016), but gender was not taken into account.

Since 2002, the central state has also required departments to identify the needs of their older population, to define their objectives and to evaluate their policies through a planning instrument called the schema gérontologique. In the schéma gérontologique départemental (SGD) 2011-2016 and 2017-2022 of the department studied, the increase in the older population is carefully scrutinized but no mention of gender appears in the "diagnosis" section, even if other data show that ageing in the department is gendered: men constitute only $36.5 \%$ of the population aged over 75 while women make up $63.5 \%$. A significant mention is made in the SGD of the burden placed on relatives of Alzheimer's patients, but APA beneficiaries' socio-demographic and gender characteristics are not broken down by department; only national data are given.

Consequently, the figures provided by the central state are the main statistics providing gendered analysis relating to the APA by establishing the proportion and characteristics of men and women among APA recipients, informal caregivers and formal paid home-based care workers. Evaluation of the policy has therefore not been gender blind since the first national survey launched on the APA (Petite and Weber 2006) carried out by the statistical office of the Minister for Social Affairs (the DREES, the Direction de la Recherche, des études, de l'évaluation et des statistiques) and gendered statistics have also been co-published with academic social scientists in the DREES Review Etudes et Résultats. In this way, social scientists' interest for gendered data and the development of gender mainstreaming within statistical publications seems to be the factors motivating the introduction of such statistics, rather than the activities of feminist organizations in the domain of elder care: indeed, it was the data produced by the DREES that prompted the delegation for equal rights between women and men at the National Assembly to act.

In French cities, gender inequalities are also becoming a greater issue (Mosconi, Paoletti, and Raibaud 2015). In the capital of the department studied, the municipality has created a service dedicated to the fight against gender inequalities and discrimination, which has helped to produce more gendered statistics in every domain. Each year, the municipality produces a document on a specific social problem and in 2014, it chose to highlight inequalities between women and men. This document listed all the domains with identified inequalities between women and men, thus enacting a 
gender mainstreaming of all municipal statistics. However, while seven pages were dedicated to childcare, only threepages presented inequalities relating to elder care. Particularly interesting is the indication by the report that, in $2014,75 \%$ of the people who contacted la maison des aidants, a municipal institution providing psychological, administrative and medical support to unpaid caregivers caring for an older person, were women. The department also published a report on gender inequalities in 2019, but gender inequalities in old age and in care practices were practically absent from it.

\section{Assessing success in outcomes and impact: Gender Accommodation}

Unlike the process of adoption of the APA and its instruments, evaluation of the policy has not been gender blind. Moreover, APA implementation has also had a gender impact, modifying the living conditions of older women, as well as those of care workers. However, although we can see an improvement in the living conditions of older people and a shift from unpaid to paid care work, gender equality has not increased. In other words, the implementation of the APA has facilitated gender accommodation by providing financial resources to different groups ofwomen, but has not transformed gender relations. We will assess the different outcomes of APA implementation for three groups of women: older people, relatives and paid care workers.

\section{Selective empowerment}

During the implementation process, civil servants have a key function in the definition of the needs and the drafting of the help plan. Nevertheless, the way the help plan is negotiated at home gives the beneficiaries and often also their families the possibility to express their will. In practice, it means that individually, women beneficiaries can be empowered through this process, when they have the possibility to express themselves. Nevertheless, it is not always the case, since some of the female beneficiaries might have lost their cognitive faculties or their aptitude to have a conversation. Besides, it is difficult for women clients to act as a collective given the allowances are administer on an individual basis. On the contrary, women as family carers are not always able to make their voice heard, since it is up to the evaluator's discretion and not the caregivers to have a dialog about the allowance's administration. Finally, care workers are ignored in the implementation process: they are neither involved with the implementation process, nor are the challenges they face in delivering care taken into consideration.

\section{Gender norms among beneficiaries}

At a national level (Legendre 2016), 20.6\% of the population aged over 75 receivedthe APA, either for home-based or institutional care, while in the department studied, in 2014, 19.2\% of the population aged over 75 (20 837 people) benefited from it. Among them, 8591 people received the allowance for home-based services. In 
comparison, in 1982, less than 6\% of the population aged over 60 (6 760 people) received benefits for home services in the department (Nogues et al. 1984: 192). The implementation of the APA has therefore increased the number of people receiving funding for care in a care home or in their own home.

While $63.5 \%$ of people aged over 75 in the department were women (and 36.5\% men), out of the 8591 people receiving the allowance for home care, $70.5 \%$ were women and $29.5 \%$ men $^{11}$. Three factors can explain why many more women than men receive the APA at home. First, cultural norms explain the assignmentof women to care activities. This can be seen when we consider the difference in couples' strategies towards care, as shown by Daune-Richard Jönsson, Ring and Odena (2012). When the man becomes dependent first, he is usually cared for by hisspouse at home, possibly with the help of a paid caregiver. After having cared for their mostly older spouses, healthy women often stay home alone (after the spouse'sdeath) and later begin to receive the APA. When the woman becomes dependent first, men, even with professional help, have more difficulties in staying at home with their wife and quickly seek institutional care for her or, often, for the two of them (Daune-Richard et al. 2012: 163). Second, it seems that the biases of the gen- der-blind universalism shared by the evaluators when deciding the help plan are central and not balanced out by the neutrality of the dependency evaluation. Evaluators encourage spousal solidarity, but as women are more likely to live with older and more dependent men, this affects women much more than men. Third, the APA, as a policy instrument, also reinforces this effect: in heterosexual couples, men have often a larger pension than women. When they die, the household's income diminishes, decreasing the user fees and increasing the incentives to ask for the APA.

Moreover, social classes react differently to the idea of in-home care, regardless of the need for financial assistance. Several agents in the department told us that they sometimes have to negotiate with older people or their families, mostly with poorer backgrounds, to encourage them to accept outside home helpers. This is related to the fact that in blue collar culture, women frequently control access to private space within the home, and some can perceive visiting caregivers as intrusive (Schwartz 1990). In contrast, white collar culture is perhaps more comfortable with domestic help in the home. Thus, the agents of the department sometimes try to modify this norm of feminine exclusivity in the domestic space.

\section{Outcomes for relatives}

For unpaid family caregivers, the APA has resulted in the provision of additional assistance in the form of paid caregivers, but has not replaced their involvement. Indeed, the reception of the APA can redefine their role and transform them into "care managers" (Petite and Weber, 2006; Campéon, Le Bihan and Martin 2012).

The task of looking for information on public services, filling in the form for the

\footnotetext{
11 Own calculations based on https://www.insee.fr/fr/statistiques/2011101?geo=DEP-44.
} 
APA, finding providers and concluding contracts with them is very demanding and does not stop after obtaining the APA: relatives continue to coordinate care and monitor the situation of the older person, leading them to often feel a significant mental burden. For women, many effects on their personal and professional life, in terms of their career progress in particular, were observed (Le Bihan and Martin, 2006, Campéon, Le Bihan, and Martin 2012).

Due to the extreme complexity of the APA's funding rules, and the diversity of actors involved in-home care, the application and monitoring procedures for the allocation (sending of invoices for example, direct employment management and use of CESU) are in themselves an additional burden. This work usually falls to the women in the family circle. When older people are isolated, they can go through a specific procedure and be looked after by a "case manager"; but most of the time this "coordination work" must be done by the relatives.

In 2013, focus groups conducted within the FLOWS project in the department confirmed that women engaged in caring for their dependent parents face many difficulties, even when their parent receives an APA-funded assistance plan (Bigoteau et al. 2015). The lack of coordination of home care, medical and hospital services was highlighted. The female participants explained in particular how emergencies impeded on their professional activities by forcing them to postpone tasks or to reorganize their schedules. However, most of them try to conform to the wishes of their parent not to seek a place in a nursing home and to stay in their own home.

\section{Gender and paid care work}

The implementation of the APA did not change the proportion of women been paid care workers, which is over $90 \%$, but changed the working and employment conditions of these paid care workers. The creation of the APA has intervened favorably in the challenging conditions of employment of home-based caregivers. Before this, employment conditions for home-based caregivers corresponded to gender norms: parttime work, poorly paid because considered to be unqualified and mostly carriedout by women (Dussuet 2005). Nevertheless, in the second half of the 2000s, the growing marketization of the sector, related to the use of other policy instruments and to austerity constraints, once again transformed the context of employment and work for all homebased care providers. When the departments had budgetary difficulties, they transferred austerity constraints onto provider organizations through the pricing system, which contributed to lowering employees' qualifications. Many provider organizations have had to review their policy of hiring and training employeesto avoid using "too many" graduates, when previously they had encouraged more skills training. The paradoxical result is that when older people fall into the IRGs 1 or 2 and need a lot of care, families tend to favour directly employed care workers, who are less qualified. Thus, the financial pressures to limit the costs of home visits prevent further efforts to decasualize or professionalize the sector and reduce by many departments the tasks performed by home-based care providers to the level of simple housework that any woman could carry 
out. These jobs are then paid at the minimum wage.

Moreover, the care time financed by the help plans and especially the routinized time defined by the department studied is more and more fragmented. Several home visits of half an hour now replace the longer house calls of the past, imposing longer travel times between homes for the employees. In cases where beneficiaries benefit from $20 \mathrm{~h}$ of help per month to fulfil bodily needs (like taking a shower or preparing the lunch/dinner), home visits must take less than an hour. The consequences for the caregivers have been a greater mobility between places of residence and more complex scheduling of work. Here we can clearly identify a process of labour intensification that originates in the terms of the help plans and which is imposed by funding considerations. This is a major constraint, making the establishment of full-time schedules for employees virtually impossible. It is also the result of a restrictive definition of working time reduced to the period of the activity in the homes of beneficiaries.

The consequence of this is that most care workers work part-time. Yet when inhome caregivers work $25 \mathrm{~h}$ a week part-time, they are, because of the obligations related to their job (travel, coordination time, training time), busy working for atime corresponding to an average of $35 \mathrm{~h}$ or a full-time job (Dussuet 2005; Barrois and Devetter 2012; Avril and Cartier 2014). Home-based caregivers are dam- aged by the fragmentation of home visits and the intensification of their work, whichconsequently induce health risks. This explains why many employees, especially older ones, prefer to limit their working time, and do not ask to work full-time. Eventhough they would increase their income by working full-time, they want above all to be able to keep their job as long as possible, to accumulate retirement pension rights. Most of them do not feel able to withstand the physical and mental demands of a full-time job that requires much more than $35 \mathrm{~h}$ per week.

\section{Conclusion}

When the problem was introduced onto the agenda in the late 1990s, the APA did not address any of the gendered dimensions of care, from the inequalities between older female and male care recipients to those suffered by paid and unpaid caregivers and care workers on the job market. Later on, feminist movements and agencies began to reframe the questions related to elder care but could not really change the nature of the implementation: introduced as a gender-blind instrument, the APA remains gender neutral in practice. Studying its implementation in one department, we have shown that the gender-neutral republican universalism is not always gen- der biased and for some specific policy instruments-like the evaluation of thecare recipient's dependency level - it prevents a reinforcement of gender assignments visible in other configurations. For example, in the department in question, those already helped informally and voluntarily by their spouses or children arenot considered to be less dependent than those living alone and the evaluation ofthe dependency level makes it possible to unburden wives and daughters caring for their spouse or father/father-in-law. However, we also show that even if the policy instrument is in theory gender neutral, in practice, 
when it comes to the definitionof the help plans, it accommodates gender norms and embraces archetypes of masculine and feminine roles, reinforcing assignments of women to care. Moreover, it should not be forgotten that the development of paid homebased care has gone handin hand with a reduction in support for nursing homes, and the weakening of institutional care. Nevertheless, this policy has also facilitated a shift from unpaid to paid and declared care work, thereby providing economic resources for women and promoting their integration into the labour market. However, this work remains precarious and the burden for unpaid family carers remains heavy due to the complexity ofthe APA, while paid caregiver jobs remain female jobs, precarious and low paid. Looking at the implementation of the APA shows that this allowance has interacted with gender roles and social class, reconfiguring inequalities in the domain of care work but has not achieved a system which could induce men to share care tasks withwomen, like the universal caregiver model promoted by Nancy Fraser (Fraser 1994). The gender biases related to French republicanism also remain unaffected by APA implementation.

Acknowledgements We would like to thank "chaleureusement" Amy Mazur, Gwenaelle Perrier and all the GEPP team who helped us to improve the content of this paper. Many thanks to Sophie Garnier for her clear understanding of legal texts and also to Joanne Walker and Amy Mazur who helped us pre-sent our results in English. This work was supported by the Agence Nationale de la Recherche (ANR) [ANR17-CE26-0019].

\section{References}

Anttonen, A., and J. Sipilä. 1996. European social care services: is it possible to identify models? Journalof European social policy 6(2): 87-100.

Avril, C. 2014. Les aides à domicile: un autre monde populaire. Paris: La Dispute.

Avril, C., and M. Cartier. 2014. Subordination in home service jobs: Comparing providers of homebasedchild care, elder care, and cleaning in France. Gender \& Society 28(4): 609-630.

Barrois, A., and F.-X. Devetter. 2012. Aides à domicile: un régime temporel non stabilisé qui témoigne des ambiguïtés d'une professionnalisation inachevée. DREES, Dossiers solidarité santé 30: 29-46.

Belorgey, N. 2017. The social construction of dependency controversies around an assessment instrumentin France. In Framing age, contested knowledge in science and politics, ed. I. Lotteier, B. Majerus, and T. Moulaert, 166-186. London: Routledge.

Bigoteau, M., B. Chaudet, A. Dussuet, and C. Péribois. 2015. Female labour market integration in thecity of nantes and care policies for older people: The French puzzle. In Local welfare policy making in European cities, ed. D. Kutsar and M. Kuronen, 179-193. New York: Springer.

Bonnet, C., E. Cambois, C. Cases, and J. Gaymu. 2011. La dépendance: aujourd'hui l'affaire des femmes, demain davantage celle des hommes? Population et sociétés 483: 1-4.

Brunel, M., and A. Carrère. 2017. Les personnes âgées dépendantes vivant à domicile en 2015. Premiers résultats de l'enquête CARE «ménages» ». Etudes et Résultats DREES (1029).

Campéon, A., B. Le Bihan, and C. Martin. 2012. La prise en charge des personnes âgées dépendantes en Europe: le vécu des aidants familiaux. Vie sociale 4: 111-127.

Comité d'étude des problèmes de la vieillesse. 2014 [1962]. Rapport Laroque, Paris : L'Harmattan. Commaille, J. 2001. Les injonctions contradictoires des politiques publiques à l'égard des femmes. In Masculin-féminin: questions pour les sciences de l'homme. Ed. J. Laufer, M. Maruani, and C. Marry : 129-148. Paris: PUF. 
Da Roit, B., and B. Le Bihan. 2010. Similar and Yet So Different: Cash-for-Care in Six European Countries' Long-Term Care Policies. Milbank Quarterly 88(3): 286-309.Daly, M., and K. Rake. 2003. Gender and the welfare state: Care, work and welfare in Europe and the USA. Cambridge: Polity Press.

Daune-Richard, A.-M., I. Jönsson, M. Ring, and S. Odena. 2012. L'entrée en dépendance des personnes âgées : quelle prise en charge pour quelles différenciations sociales et sexuées? Revue française desaffaires sociales 2: 148-168.

Devetter, F.-X., A. Dussuet, and E. Puissant. 2017. Pourquoi les aides à domicile sont-elles davantage rémunérées dans certains départements ? Revue d'économie rurale et urbaine 2: 239-270.

Devetter, F.-X., F. Janny-Catrice, and T. Ribault. 2009. Les services à la personne. Paris: La Découverte. Dubois, M. 2011. Rapport d'information au nom de la Délégation aux Droits desFemmes et à l'égalité des chances entre les hommes et les femmes sur le genre et la dépendance. Paris: Assemblée Nationale.

Dussuet, A. 2005. Travaux de femmes: enquêtes sur les services à domicile. Paris: L'Harmattan.

Engeli, I., and A. Mazur. 2018. Taking implementation seriously in assessing success: the politics of gen-der equality policy. European Journal of Politics and Gender 1(1-2): 111-129.

Ennuyer, B. 2004. Les malentendus de la dépendance: de l'incapacité au lien social. Paris: Dunod. Esping-Andersen, G. 1990. The three worlds of welfare capitalism. Princeton: Princeton University Press.Fouquet, A., M. Laroque and C. Puydebois. 2009. La gestion de l'allocation personnalisée d'autonomie.

Synthèse des contrôles de la mise en oeuvre de l'APA réalisés dans plusieurs départements, Rapport de l'IGAS.

Frinault, T. 2009. La dépendance: Un nouveau défi pour l'action publique. Rennes: Presses Universi-taires de Rennes.

Gallot, F., and E. Meuret-Campfort. 2015. Des ouvrières en lutte dans l'après 1968. Rapports auféminisme et subversions de genre, Politix 109(1): 21-43.

Gramain, A., S. Billaud, and J. Xing. 2015. La visite à domicile dans le cadre de l'APA: quel effet de laformation initiale des personnels sur leurs pratiques? Notes MODAPA.

Hobson, B., J. Lewis, and B. Siim. 2002. Contested concepts in gender and social politics. Cheltenham:Edward Elgar Publishing.

Howlett, M. 2010. Designing public policies: Principles and instruments. London: Routledge.

Jenson, J. 1997. Who cares? Gender and welfare regimes. Social Politics: International Studies in Gen-der, State \& Society 4(2): 182-187.

Lagrave, R.-M. 2009. Ré-enchanter la vieillesse. Mouvements 3: 113-122.

Lascoumes, P., and P. Le Galès. 2005. Gouverner par les instruments. Paris: Presses de Sciences Po.

Le Bihan, B., and C. Martin. 2006. Travailler et prendre soin d'un parent âgé dépendant. Travail, Genre et Sociétés 16: 77-96.

Le Bihan, B., and C. Martin. 2010. Reforming Long-term Care Policy in France: Private-Public Comple-mentarities. Social Policy \& Administration 44(4): 392-410.

Ledoux, C. 2018. Etat Providence et mondes professionnels. Revue française de science politique 68(1): 53-76.

Ledoux, C. 2011. L'Etat-providence et les mondes professionnels : la construction politique des métiers féminisés d'intervention dans la sphère privée. Une comparaison France-République fédérale d'Allemagne depuis les années 1970. Thèse pour l'obtention du grade de docteur en science politique. Paris: Institut d'Etudes Politiques de Paris.

Legendre, S. 2016. Six bénéficiaires de l'allocation personnalisée d'autonomie sur dix vivent en établissement. INSEE Flash Pays de la Loire 53: 1-2.

Leitner, S. 2003. Varieties of familialism. European Societies 5(4): 353-375.

Lépinard, E. and A. Mazur. 2009. Republican universalism faces the feminist challenge: The continu-ing struggle for gender equality. In The French Fifth Republic at Fifty. Beyond Stereotypes. Ed. S. Brouard, A. Appleton and A. Mazur: 247-66. Basingstoke: Palgrave. 
Giraud, O., B. Lucas, K. Falk, S. Kümpers, and A. Lechevalier. 2014. Innovations in local domiciliary long-term care: From libertarian criticism to normalisation. Social Policy and Society 13(03): 433-444.

Leroux, I. (ed.). 2018. L'aide et l'action sociales en France, Panorama de la DREES. Paris: DREES. Lipsky, M. 1980. Street-level bureaucracy: dilemmas of the individual in public services. New York: Russel Sage Foundation.

Lewis, J. 1998. Gender, social care, and welfare state restructuring in Europe. Aldershot: Ashgate. Lewis, J. 1992. Gender and the development of welfare regimes. Journal of European social policy 2(3): 159-173.

Moignard, J. 2014. Rapport d'information au nom de la délégation aux droits des femmes et à l'égalité des chances entre les femmes et les hommes sur le projet de loi relatif à l'adaptation de la société au vieillissement. Paris: Assemblée Nationale.

Morel, N. 2007. From Subsidiarity to'Free Choice': Child-and Elder-care Policy Reforms in France, Bel-gium, Germany and the Netherlands. Social Policy \& Administration 41(6): 618-637.

Mosconi, N., M. Paoletti, and Y. Raibaud. 2015. Le genre, la ville. Travail, genre et sociétés 1: 23-28.

Mulet, P. 2014. «Évaluer la dépendance: jeux et enjeux autour de la codification», in Weber F., L.Trabutand S. Billaud, Le salaire de la confiance. L'aide à domicile aujourd'hui: 195-215, Paris: Editions rue d'Ulm.

Nogues, H., D. Bouget, G. Brovelli, and J. Tymen. 1984. Politique d'aide-ménagère aux personnes âgéesen Loire Atlantique. CNRS, Paris: Commission Générale du Plan.

Pennec, S. 1999. Les femmes et l'exercice de la filiation envers leurs ascendants, in A. Guillou and Pen- nec S. Les parcours de vie des femmes, Paris : L'Harmattan.

Petite, S., and A. Weber. 2006. Les effets de l'allocation personnalisée d'autonomie sur l'aide dispensée aux personnes âgées, 459. Etudes et résultats: DREES.

Ramos-Gorand, M. 2016. Le non-recours à l'APA à domicile vu par les professionnels de terrain, Les dossiers de la DREES, 10.

Ranci, C., and E. Pavolini. 2012. Reforms in long-term care policies in Europe: Investigating institutionalchange and social impacts. New York: Springer.

Renaut, S. 2000. L'aide bénévole auprès des personnes âgées ou la place particulière des femmes au cœurd'un principe de solidarité. Droit et société 31: 247-264.

Schwartz, O. 1990. Le monde privé des ouvriers. Paris, PUF: Hommes et femmes du Nord.

Sineau, M., and J. Jenson. 2003. Who cares? Women's work, childcare, and welfare state redesign. Toronto: University of Toronto Press.

Ungerson, C., and S. Yeandle. 2007. Cash for care in developed welfare states. Basingstoke: Palgrave. Van Hooren, F., B. Apitzsch, and C. Ledoux. 2019. «The politics of care work and migration». In The Routledge Handbook of the Politics of Migration in Europe. Ed A. Weinar, S. Bonjour and L. Zhyznomirska: 363-373. New York: Routledge.

Weber, F., S. Gojard, and A. Gramain. 2003. Charges de famille: dépendance et parenté dans la France contemporaine. Paris: La Découverte. 